\title{
Post-trial access to medication: an approach based on different knowledge
}

\author{
Acesso pós-teste à medicação: uma abordagem baseada em
} diferentes conhecimentos

Bruno Rodolfo Schlemper Junior* Aline Albuquerque **

\section{Abstract}

This article approaches clinical trials to test medication in Brazil, and its goal is to analize the issue of post-trial access to drugs that have proven to be beneficial to the research participants from the ethical, sanitary, legal and of the human rights perspectives. In order to do so, a revision was conducted of the main national and international norms, including the normative documents related to human rights and judicial rulings pronounced by the national Courts. It is concluded that there have been important advances in this field, shown by the consensus that the research participants must have total access to the benefits explained in the project and, in Brazil, these benefits are particularly supported by Resolution No 466/2012 of the National Health Council, by the Resolution of the Board of Directors No 38/2013 of the National Health Surveillance Agency and by judicial rulings. Moreover, from the perspective of the human rights, it is established that denying the post-trial drug access represents a violation of the human right to health.

Keywords: Biomedical research. Ethics in research. Clinical Trial. Human Rights

\section{Resumo}

O presente artigo versa sobre ensaios clínicos para teste de medicamentos no Brasil, tendo como objetivo analisar o tema do acesso à droga pós-estudo que se mostrou benéfica aos participantes das pesquisas sob a perspectiva ética, sanitária, jurídica e dos direitos humanos. Para tanto, foi feita uma revisão das principais normas pertinentes nacionais e internacionais, incluindo as normativas de direitos humanos e das decisões judiciais proferidas pelos Tribunais nacionais. Conclui-se que ocorreram avanços expressivos neste campo, revelado pelo consenso de que os participantes do estudo devem ter acesso total aos benefícios explicitados no projeto. No Brasil, os participantes estão amparados, sobretudo, na Resolução No 466/2012 do Conselho Nacional de Saúde, na Resolução de Diretoria Colegiada No 38/2013 da Agência Nacional de Vigilância Sanitária e em decisões judiciais. Ainda, à luz dos direitos humanos, constata-se que a negativa do acesso à droga pós-estudo representa violação ao direito humano à saúde.

Palavras-chave: Pesquisa Biomédica. Ética em pesquisa. Ensaio Clínico. Direitos Humanos.

DOI: 10.15343/0104-7809.20164004498508

\footnotetext{
* University of the West of Santa Catarina. Joaçaba, Santa Catarina/Brazil. E-mail: schlemper.junior@gmail.com

** University of Brasilia, Brasilia/Brazil. E-mail: alineaoliveira@hotmail.com

The authors declare no conflicts of interest.
} 


\section{INTRODUCTION}

The ethical norm regulating clinical trials in human beings that is more commonly used in the world is undoubtedly the Declaration of Helsinki (DoH), which, although elaborated by the World Medical Association (WMA, 2013) ${ }^{1}$ is used as an ethical guide in research involving human beings in all fields of knowledge. This Declaration was written for the first time in 1964 due to the lack of international codes and ethical norms that could guide these studies. There were revisions of the $\mathrm{DoH}$ in 1975, 1983, 1989, 1996, 2000 (clarification notes in 2002 and 2004), 2008 and 2013. Only in 2000 was the subject of post-trial obligations approached for the first time, and its text affirms that: At the end of the study, all the participant patients must have been ensured access to the best proven prophylactic, diagnostic and therapeutic methods identified by the study" (WMA, 2000)2. It is important to point out that this is the revision of the DoH officially accepted in Brazil, referred to in the preamble of the national ethical norms.

At that time, there were intense political debates during the General Meetings of the $\mathrm{DoH}$ among the developed countries, which considered a flexibilization of this version, and the developing countries, which yearned to guarantee more efficient protection to the participants of clinical trials. The points of greater discord were, above all, the use of placebo and the access to the benefits after the research was concluded. This event became known as the "Battle of Helsinki" 3 .

However, as these advances continued to be subjected to pressure and doubts, the WMA edited a clarification note to paragraph 30 of the DoH (2000), in 2002 and 2004, but that didn't bring any positive results to nullify the doubts. Hence, in the 2008 revision, changes were introduced that resulted in the approval of a text that also allows for unfavorable interpretations to the participants of clinical trials, as the text uses words like "reasonable probability" and "other appropriate cares or benefits", without defining their real meaning, making it possible to offer secondary benefits not directly related to the results obtained in the study. These and other controversial points assumed by the 2008 revision of the DoH caused the controversies to persist in relation to the post-trial cares ${ }^{4}$. Thus, the present work analyzes the various national and international sources that approach posttrial access, not only in light of the norms on ethics in research, but also from the perspective of the Brazilian sanitary control, the national Judicial Power and the aspects related to human rights.

\section{REGULATIONS}

\section{Ethical regulation in the international framework}

The main international ethical documents that deal with this subject are the International Organizations of Medical Sciences - CIOMS ${ }^{5}$, version of 2016 of the International Ethical Guidelines for Biomedical Research Involving Human Subjects. This document is very clear when attributing to the researcher and the sponsor the responsibility of supplying the drug and monitoring the participants in the cases when the medication is beneficial. This mentioned norm advises that this access must also be given in the interval between the end of the patient's participation in the study and the conclusion of the research, and that, in this in case, the sponsor must provide the access in extension study or compassionate use. In addition, the norm admits that the sponsor and the researcher do not need to supply the drug when it is made available by the public service, since the supply for a definite time is agreed upon with the participants before the beginning of the study, and the research ethics committees have to make this evaluation.

An international document of interest that also approaches the ethical issues related to research in developing countries is the Nuffield Council on Bioethics ${ }^{6}$ (The ethics of research related to healthcare in developing countries 2002), whose report specifies that, before the trial starts, investigators must guarantee that the participants will have access to the efficient interventions after the trial is concluded.

Another international program, the United Nations Programme on HIV/AIDS, 2007 (7 
UNAIDS/WHO), in its document Ethical Considerations in biomedical HIV Preventive trials designates that "volunteers that are infected during preventive trials must have access to the treatments considered internationally as excellent". The document refers to the bioethical principles of beneficence and justice (as reciprocity) and to equal treatment in similar cases; that is, the same therapeutic method used in developed countries must be made available to the participants who became infected in developing countries. This is an international consensus that must always be remembered and required from the sponsors of clinical trials.

Also important is the document of the National Bioethics Advisory Commission 2001 (United States of America) $)^{8}$, entitled Ethical and policy issues in international research: clinical trials in developing countries. In the Chapter When Research Is Concluded - Access to the Benefits of Research by Participants, Communities, and Countries, the Commission recommends that researchers and sponsors of clinical trials must make reasonable efforts to guarantee to all participants the continued access to the experimental interventions that have shown to be efficient, specifying the access period, extension and financing.

This aforementioned commission goes even further in its ethical analysis when recommending that the protocols must include an explanation of how these new efficient interventions will be made available for part or for the totality of the population of the host country. On this subject, the principle of justice, like equality, is applied to justify the extension of the benefit to other community members who have the same illness as the participants of the study. Contrary to this recommendation, the directive of the European Community that deals with trials carried out in countries outside its region (EMA/121340/2011 - Directive 2001/20/EC The European Medicines Agency Working Group on Clinical Trials conducted outside of the EU/ $E E A)^{9}$ establishes that the continuation of the access to the product identified as beneficial is essential, but it states that the access by other patients outside the trial granted by the same sponsor or investigator is not appropriate, as it is not able to solve flaws in the national or regional health systems. This, however, is not what is stated in the Universal Declaration on Bioethics and Human Rights/UNESCO10 which, when approaching the sharing of the benefits of the clinical trials broadly specifies that (Art. 15) the benefits resulting from any scientific inquiry and from its applications must be shared with the society in its entirety and in the international community, in particular in developing countries, clarifying that to make this principle effective, the benefits can assume other ways of support, as long as they do not constitute in improper incitements to the participation in the clinical trial.

Finally, due to its importance, the 2013 Declaration of Helsinki deserves more detailed comments (WMA, 2013)'1, although the divergences among the national medical entities continued to be evident, reproducing the confrontations occurred in the previous versions of the $\mathrm{DoH}^{11}$. This is because the final text of the $\mathrm{DoH}$, despite having been approved by the Brazilian Medical Association, was rejected by the Federal Council of Medicine (CFM) and by the medical entity of Latin America and the Caribbean (Confederación Médica Latinoamericana y del Caribe - CONFEMEL, 2013)12, also having received harsh criticism from Latin American researchers ${ }^{4}, 13,14$. When approaching the After-Trial Provisions, the $\mathrm{DoH} / 2013^{1}$ approved article 34: Before a clinical trial, sponsors, researchers and governments of host countries must make provisions to provide post-trial access to all the participants who still need an intervention identified as beneficial in the trial. Kottow $(2014)^{14}$, when criticizing this statement, affirms that there is no binding declaration that ensures this access and, infuriated with the final terms, suggests that Latin America should abandon the WMA normative and create its own ethical document which is more centred on the regional reality.

In general, the terms of the $\mathrm{DoH} / 2013$ refer to the necessity of previous information and special cares given to vulnerable groups, but it dilutes the responsibility of ensuring the benefits, when it adds that the host countries must also make provisions to guarantee the supply of the beneficial interventions. In fact, when making the governments responsible, without their consent and failing to identify specifically who must provide such type of benefit, 
the recommendation becomes extremely vague and it will allow the occurrence of the phenomenon of transference of responsibilities, from the private to the public, as it always occurs on similar occasions.

This was the strategy used in Brazil by the sponsors of clinical trials, as, some years ago, the protocols of research of new pharmaceuticals suggested transferring the responsibility to provide the beneficial medications to the volunteers upon the conclusion of the study to the Unified Health System. However, thanks to energetic, coherent and permanent action from the National Research Ethics Committee (CONEP), this ethical nonsense was gradually reverted and this situation was not accepted anymore in the research protocols. Thus, the sponsor was formally required to guarantee the supply of the beneficial drug free of charge and for as long as needed ${ }^{15}$. In addition, the followup assistance from the doctor of the study, with the sponsor's supervision and for an unlimited time period, as long as it is beneficial to the patient, was already suggested ${ }^{15}$.

However, it is not known if this is what really happens in real life, since the follow-up process and the control of the clinical trials are still flawed in Brazil; up to now, there has been no reasonable way of obtaining more accurate information. It is expected, however, that with the current sanitary norm, the RDC N 38/2013 ${ }^{16}$, whose Art. $^{17}$ establishes that the sponsors must send annual reports on the post-trial access program, this information becomes of public domain, but respecting the participants' privacy.

\section{Brazilian normative ethics}

At different moments, the ethical norms established by the National Health Council $(\mathrm{CNS})^{17}$ both maintain the same guarantee to protect the participants and present interesting developments that better specify the participants' rights. Regarding the ethical documents in force, Resolution CNS No 251/97, which approaches the studies on new pharmaceuticals, vaccines and diagnostic tests, is very clear when stating that one must: IV. $1 \mathrm{~m}$ - ensure, on the part of the sponsor or, in its absence, on the part of the institution, researcher or promoter, the access to the investigational drug, if its superiority in relation to the conventional treatment is proven. Finally, Resolution CNS No 466/2012 included new ethical advances, which had been neglected in the previous norm. Thus, known as the mother normative, this Resolution establishes that one must: III.2 - n) ensure to the participants of the research the benefits resulting from the project, either in terms of social return or access to procedures, products or agents of the research; III.3 - The research that uses experimental methodologies in the biomedical area, involving human beings, besides what is stated in item III.2, must: ensure to all the participants at the end of the trial, on the part of the sponsor, free access and for an indefinite time, to the best prophylactic, diagnostic and therapeutic methods that have proven to be efficient; the access will also be guaranteed in the interval between the end of the individual participation and the end of the study, being possible, in this case, that this guarantee be given by means of extension study, according to the analysis duly justified from the participant's assistant doctor. In order to keep the participants better informed of their rights, the ethical norm determined that the Term of Free and Clarified Consent must contain, obligatorily, clarification regarding the follow-up assistance that the participants will be entitled to receive, as well as benefits and further followup after the study has been concluded. Finally, when approaching the risks and benefits, the Resolution advises that "In research in the area of health, as soon as it is proven the significant superiority of an intervention compared to another, the researcher will have to evaluate the necessity to adjust or suspend the study in course, aiming to offer the benefits of optimum regimen to all". Thus, it can be observed that this ethical norm has filled some gaps and clarified doubts, having clearly and objectively consecrated the ethical rights of the participants in relation to the post-trial access to beneficial drugs.

\section{Brazilian sanitary normative}

In 2013, ANVISA finally approved the RDC No 38/2013 ${ }^{16}$, which represents a great advance and gives more importance to the requirement of fulfilling the same norms on the part of sponsors and doctors responsible for the study. This sanitary norm approved 
the regulation for the programs of expanded access, compassionate use and after-trial medication access, presenting interesting innovations long desired by those who work on the Brazilian ethical control system and defend the participants' rights and safety. By definition, the post-trial drug access program must make the medication available and free of charge to the subjects of the research in the cases of concluding the trial or after the patients' participation in the study. This aforementioned resolution, in a broad and unquestionable way, met the expectations of the participants' protection by attributing to the doctor of the study the responsibility to: a) issue a justified request of the product to the sponsor; b) provide medical assistance in case of complications and/or damages resulting from the predicted and unpredicted risks; c) notify the sponsor of the occurrence of serious adverse events, thus ensuring the full follow-up assistance to the participants who were benefited by the use of the experimental drug. In relation to the sponsor, the responsibilities are: a) to supply free and full treatment using the medication; b) to provide the financial aid related to the full assistance in case of complications and/or damages resulting from predicted and unpredicted risks; c) to provide free medication access to patients with chronic diseases, as long as it is beneficial to the patients (Art. $6^{\circ}$ ). This timely resolution came to solve many controversial and contradictory points related to the post-trial drug access and pressured the pharmaceutical industry so that it makes the due donation of the medication in the situations mentioned above.

It is important to state that, before its approval, ANVISA requested the Federal Council of Medicine (CFM) in October/2011 to make an ethical analysis on this resolution and, specifically, on the necessary period of time in which the sponsor must donate the post-trial medication in case it is beneficial. In 2012, Opinion CFM 31/2012 was approved (CFM, 2012)18, which clarifies the doubt when concluding that no interruption to the treatment should occur, therefore, the use of the medication must be foreseen and it must be made available immediately at the end of the participation of patient in the clinical trial [...]. The sponsor must supply the medication while it is beneficial to the patient, according to a medical evaluation, including in cases of chronic disease.

\section{Post-trial drug access under the legal perspective}

Without aiming to present an extensive research in this field, the authors intend to display a general view on the approach of this topic in the scope of the legal agencies pertaining to the national structure within the Judicial Power and the Executive Power that deal with the protection of the participants' rights, as seen below:

1. Supreme Court - Report by Minister Gilmar Mendes ${ }^{19}$ presented in the Suspension of Judicial Protection no. 244 of 18.09.2009 relates that: the participation in these treatments is conducted by the norms that regulate medical research and, thus, the State cannot be obliged to supply them. (...) However, it is necessary that the laboratory conducting the research continues to supply the treatment to the clinical trial patients, even after the trial is concluded.

2. National Justice Council (2010) - In view of the increasing growth of the phenomenon of health judicialization by means of medication and/or procedures, the National Justice Council, aiming to separate the demands resulting from clinical trials and to guide the Courts, edited Recommendation no. $31 / 2010^{20}$, so that: b.4. they verify, together with the National Research Ethics Committee (CONEP), if the petitioners are part of laboratory programs of experimental research, in which case they must be responsible for continuing the treatment.

3. Attorney General's Office (2012) Federal Consultant General - Legal Consultant together with the Ministry of Health - Opinion AGU/CONJUR-MS/HRP No 806/2012 ${ }^{21}$ : "One concludes that, in the realm of scientific research involving human beings, the legal responsibility of the sponsor of the research the pharmaceutical laboratory, in the sense of paying for all the necessary medical treatment, including any type of medication in favor of the subjects of the research, after the trial has been concluded - is inalienable and non-transferable, and the laboratory must be immediately responsible for the expenses of all the patients who prove to have been subjects of the trial". 
4. The Rio Grande do Sul State Court of Justice - Due to the insistent refusal by the foreign laboratories in supplying posttrial medication, appeals petitioned by the participants of research start to reach the Judiciary Power, albeit timidly. First, the lawsuits are brought against the State for the supply of the medication, but the judges' rulings have been granted in the sense of assigning the responsibility to the sponsors of the clinical trials. These reduced lawsuits do not mean, in any way, that the sponsors are completely fulfilling their commitments and assuming their responsibilities established in the ethical and sanitary norms, since some lawsuits run under legal confidentiality, upon the request from the sponsors, which hinders the lawsuit monitoring. Thus, the authors present parts of the analyses and the final decision of a paradigmatic case that occurred in 2009 at the Rio Grande do Sul Court of Justice, which, after analysis, ruled that the pharmaceutical laboratory must continue to supply the experimental drug after the trial, as long as the patient's illness lasts and as long as there is a medical prescription for the treatment (Court of Justice of Rio Grande do Sul. Juvenile Court (2 $2^{\underline{a}}$ Vara da Infância e da Juventude. Process No 1625854. 2009) ${ }^{22}$.

The Magistrate concluded:

"And he asserted that the defendants clearly behaved in bad faith: they cannot look for a person, invite him/her to participate in a study and, after the experimental drug is discovered/improved, they demand that the research subject require from the State, by means of an uncertain lawsuit, the medication that he/she has decisively helped to develop, warning that denying the research subject the access to the medication after having used his/her body as a "living laboratory" is to disrespect the patient's dignity as a human being".

At that time, the multinational company alleged, among other reasons, that: a) there was no ethical or legal obligation to supply the medication to the research participant; b) the agreement with the patient would terminate upon approval of the experimental drug by the regulating agency; c) it is the Brazilian State's duty to supply medication to the citizens. It is perceived that these arguments are misleading and that they are not supported by any ethical, sanitary or legal norm, but they serve to illustrate what can be expected with the new wording of $\mathrm{DoH} 2013$, to share with the State the responsibilities to provide the drugs in cases when they are beneficial to the participants of clinical trials. Undoubtedly, this represents an unacceptable setback and deserves to be repudiated by the national system of ethics in research.

5. Public Prosecution Office. $4^{\text {th }}$ Region of the Office of the Attorney General, 2013. Opinion 403E/13/MPF/PRR4/HJ (Process No 503415697.2012.404.7100 $)^{23}$. When deciding favorably to the volunteer of the research against the laboratory that refused to supply the medication that had benefited the patient, the judge firmly concluded that:

It is the responsibility of the Pharmaceutical Laboratory who is sponsoring the research with experimental drugs to ensure to the participants in the clinical trials free access to the best prophylactic, diagnostic and therapeutic methods that have proved to be efficient, for an indefinite period of time. Constitutional Law, Civil Law, Civil Procedural Law and Ethics in research with human beings do not assent with the pretension of the Pharmaceutical Laboratory to cease to supply the medication to the petitioner after this medication has been registered at ANVISA.

\section{The post-trial drug access from the perspective of the theoretical-normative reference of the human right to health}

Post-trial drug access can be analyzed based on different references, which allows to broaden the understanding of this issue and to improve the decision-making regarding the obligation or not to provide the access, its limitations and the people responsible for its payment. Considering the relevance to reflect on the subject under various perspectives, the objective in this stage is to analyze the post-trial drug access under the light of the theoretical-normative reference of the human right to health.

The conceptual landmark of the human right 
to health is its main normative, which is article 12 of the International Covenant on Economic, Social and Cultural Rights. Based on this document, the human right to health must not be understood as the right to be healthy, but as the right that encompasses freedom, as well as the right to healthcare units, products and services $^{24}$.

The human right to health, in all its forms and levels, includes the following elements: availability; accessibility; acceptability and quality. Availability implies the duty of the States to have sufficient healthcare units, products and public services. Accessibility includes the following dimensions: non-discrimination, physical accessibility, economic accessibility, and access to information. Acceptability means that all the healthcare units, products and services must comply with the medical ethics and be culturally appropriate. Quality implies that healthcare units, products and services are appropriate from the scientific and medical point of view ${ }^{24}$.

The right to drug access was first recognized as a human right by the international community by means of Resolution 2001/33, adopted by the UN. In 2002, a new UN Resolution, the 2002/32, endorsed the first, establishing the nature of the right to drug access as an essential element of the human right to health. In this sense, Resolutions are produced by the UN Commission of Human Rights, such as the 2003/29, 2004/26 and 2005/23, endorsing the concept that the right to drug access is part of the human right to health ${ }^{25}$.

During the process of reaffirmation of the concept of the right to drug access under the perspective of the human rights, Hunt $(2006)^{26}$ consolidated, in his 2006 Report, the human right to medication access, emphasizing its bond to other human rights, such as the right to health and the right to life. In fact, Hunt applied to the issue of drug access the theoreticalnormative reference of the human right to health, especially its elements, which was later investigated by Grover in his Report of 2009, in which he states that the attention to health in cases of illnesses, and the prevention and control of diseases entail access to medication, hence consisting an inseparable part of the human right to health ${ }^{27}$.
Hunt $(2006)^{26}$ introduces a new aspect to the reflections on the right to drug access, which is the debate regarding the individuals who must meet the requirements resulting from such right (duty-bearers). According to the author, the State and the pharmaceutical companies have relative obligations related to the right to drug access, which derive from many international normative documents that establish the human right to health. In relation to the State, government agents must make all the necessary efforts so that the existing medication is available in sufficient amounts in their jurisdiction.

The States must adopt measures to promote the development and the availability of new medication, vaccines and diagnostic methods. Besides being available, the medication must be accessible, which imposes the duty to ensure its access by low income populations. In addition, the medication must be acceptable, implying that the state must guarantee that the clinical trials are ethical. In addition, it is the State's duty to ensure the medication quality, adopting normative rules that establish ways to prove its effectiveness and quality ${ }^{26}$.

Hunt $(2006)^{26}$ points out that, although the responsibility of the State is primary in the sense of complying with the obligations resulting from the right to drug access, private entities, such as transnational pharmaceutical corporations, also have responsibilities, hence giving rise to a shared responsibility between state agents and private entities. In this sense, various practices by the pharmaceutical sector may violate the right to drug access, for example setting absurdly high prices, erratically donating medication, promoting inadequate medication, and by using inadequate research activities ${ }^{26}$.

The Millenium Development Goals (2000) recognized that the pharmaceutical corporations share responsibilities in relation to drug access ${ }^{28}$. The Guidelines to Pharmaceutical Corporations in Relation to the Drug Access confirm the responsibilities of the pharmaceutical companies regarding human rights, and this document stresses the recommendation that the pharmaceutical corporations incorporate the human right to health into their policies and strategies.

Post-trial drug access from the perspective 
of human rights has two approaches: the first understands this access as an element of the right to drug access, and the second, to the dutybearers correlated to this right. First, it is stated that the participants of clinical trials have the right to receive the experimental drug, whose effectiveness was proved. In other words, the experimental drug access is one of the aspects of the human right to drug access, which is an inseparable element of the human right to health.

The right to drug access is unfolded into distinct contexts: of essential medication, according to the list of the $\mathrm{WHO}$; of medication related to neglected illnesses; and of medication targeting certain diseases like AIDS; thus, depending on the situation, there will be specific instructions as to the ways to grant access for the parties that are due to supply it and for the individuals that will receive the medication. In this sense, despite the peculiarities of each case, everybody is included in the right to have access to medication, including post-trial drugs, which are included in this right. In fact, drug access is a human right, regardless of it being prescribed or not in a term of assent or agreement between the parties.

The approach to post-trial drug access based on the human rights is not current, so it is a challenge to face the problem regarding the party who is due to supply the drug. The focus of this analysis will fall on the pharmaceutical corporations, in accordance with the studies developed by Ruggie (2008) ${ }^{29}$ and Hunt $(2006)^{26}$, considering that there is a controversy in the bioethic literature concerning the responsibilization of the clinical trial sponsors, which are the pharmaceutical corporations in this case. Blackmer and Haddad $(2005)^{30}$ say that there is a widely shared agreement that the responsibility to supply the medication belongs to the health systems, and not to the clinical trial sponsors. In the general model of human rights obligations, the responsibility lies primarily with the State.

However, in fact, when it comes to the right to drug access, the responsibility is shared between the State and private entities. In the Guidelines mentioned before, it is stated that the pharmaceutical corporations, when elaborating their access policies, will ensure that their drugs are accessible to the highest number of people, which includes the adoption of different measures, such as policies related to low prices, volunteer licenses, and donations. Concerning donations, the corporations have to guarantee that they are inclusive and are free of unnecessary bureaucratic obstables. Thus, the pharmaceutical corporations have the human right obligation to extend the drug access to all, which can be made possible by means of a careful donation program ${ }^{26}$.

Lee and Hunt $(2012)^{28}$ present a detailed formulation concerning the responsibilization of pharmaceutical corporations in relation to drug access. Using the elements of the human right to health as reference, pharmaceutical corporations must ensure that the medication is available in sufficient amounts, and the companies must not arbitrarily terminate the supply of the medication that they produce to a particular country, region or group of people. The medication must be economically accessible to all, including low income populations.

The pharmaceutical corporation must adopt measures tending to broaden the drug access. The medication and the corretated trials must adjust to the medical ethics. The pharmaceutical companies are responsible for ensuring that their drugs are of good quality, safe and efficient. According to Lee and Hunt $(2012)^{28}$, pharmaceutical companies must show that they make all the efforts, within a viable business model, to meet their social mission and their human rights responsibilities.

Thus, pharmaceutical corporations share with the States the duty to provide post-trial drug access, from the point of view of the human rights. The advantage of building an understanding based on the human rights is that it can globally guide the problem of post-trial experimental drug access, despite the lack of national norms.

Hence, the human rights model allows the establishment of ethical-legal guidelines of ample penetration, preparing a fertile land to claim the responsibility of the pharmaceutical corporations to provide the post-trial experimental drug access. Having such an obligation in mind, it is understood that pharmaceutical corporations must establish strategical politicies and plans to donate the medication to the groups of 
participants of clinical trials within the business model, since these companies must expand the drug's access as much as possible, especially to vulnerable groups. In this sense, once the donations are inserted into strategic planning, pharmaceutical corporations can prepare themselves financially so that such donations do not cause a disproportionate financial impact. Moreover, considering the duty of the pharmaceutical corporations to respect the human right to health, that is, not to violate or to harm the rights of other people ${ }^{25}$, it is imperative that drug access not be ceased, because, if this happens, there will be damages to the patients' health ${ }^{31}$. In the same sense, due diligence implies the adoption on the part of the pharmaceutical corporations of ways to prevent and to compensate the adverse effects of their actions $^{25}$.

Thus, such corporations must monitor and foresee the consequences of their activities in relation to the human rights of the clinical trial participants. Hence, pharmaceutical corporations must prevent damages to the health of the clinical trial participants resulting from the suspension of the drug's access. Therefore, they must, without disregarding the business model, adopt strategic politicies and plans that ensure the continuous donation of the efficient drug to the research participants.

\section{FINAL CONSIDERATIONS}

The Brazilian system of ethics in research in human beings is composed by a key forum, the National Research Ethics Committee, and by Committees for Ethics in Research in Human Beings of the research institutions in the country, which currently reach the number of 765 committees. It is absolutely necessary to keep the double assessment of the international clinical trials established in Brazil, due to the enormous risks for the participants and the indispensable and rigorous analysis to be conducted in an environment outside the corporative influence and out of reach of potential conflicts of interest.

In summary, it is concluded that from the different perspectives of analysis - ethical, sanitary, legal and of the human rights - both in national documents and international ones, there is a consensus that the participants of clinical trials must be granted access to the benefits of the experimental drug after the conclusion of the research.

In Brazil, significant advances occurred in the ethical and sanitary norms due to Resolution CNS No 466/12 and RDC No 38/13, respectively. Thus, in the case of the benefit resulting from the clinical trial, the following responsibilities are assigned: 1. To the sponsor: a) to ensure the full and free supply of the medication while it is beneficial, including concerning chronic diseases; b) to ensure the import, maintenance and supply of the experimental drug; c) to monitor and register the distributed medication; d) to notify ANVISA in case of serious adverse events; e) to provide the financial aid resulting from the full assistance in case of complications and/or damages resulting from the use of the medication and of the risks, whether they were predicted or not. ${ }^{2}$. To the research doctor: a) to request the medication from the sponsor when it is beneficial to the participants; b) to notify the sponsor of serious adverse events; c) to assume the medical assistance in case of complications and/or damages resulting from the risks, whether they were predicted or not; d) to provide the sponsor with the necessary documentation to monitor the program; e) in case of change of doctors during the trial, the participant must agree with this change.

Finally, the sanitary agency may request additional information and carry out inspection visits aiming to check the fulfilment of the norm. However, it is understood that the biggest difficulty lies in the current precariousness of research control and monitoring on the part of the Research Ethics Committees and CONEP, to know if the sponsors are fulfilling the ethical requirements.

Based on these new resolutions, it is expected that the ethics system finds mechanisms to 
validate these victories to the participants and, perhaps, a bigger cooperation with the sanitary system can be useful to the achievement of these goals.

\section{REFERÊNCIAS}

1. World Medical Association (WMA). Declaration of Helsinki - Ethical Principles for Medical Research Involving Human Subjects.

2013. [cited 2015 march 29]. Available from: http://www.wma.net/en/30publications/10policies/b3/

2. World Medical Association (WMA). Declaration of Helsinki 2000. 52nd General Assembly. Edinburgh, Scotland. 2000. [cited 2015 march 30]. Available from: http://www.fda.gov/ohrms/dockets/dockets/06d0331/06D-0331-EC20-Attach-1.pdf

3. Wolinsky H. The battle of Helsinki: Two trouble some paragraphs in the Declaration of Helsinki are causing a furore over medical research ethics. The European Molecular Biology Organization (EMBO Reports). 2006;7 (7): 670-672.

4. Hellmann F, Verdi M, Schlemper Junior BR, Caponi S. 50th Anniversary of the Declaration of Helsinki: The Double Standard Was Introduced. Arch Med Res. 2014;45: 600- 601.

5. The Council for International Organizations of Medical Sciences (CIOMS/WHO). International Ethical Guidelines for Health-related Research involving Humans 2016 [cited 2016 dez 14]. Available from: http://www.cioms.ch/ethical-guidelines-2016/

6. Nuffield Council on Bioethics. The ethics of research related to healthcare in developing countries. 2002. [cited 2015 april 01]. Available from: http://www.nuffieldbioethics.org/research-developing-countries

7. United Nations Program on HIV/AIDS (UNAIDS/WHO). Ethical considerations in biomedical HIV prevention trials. [Additional guidance point added in 2012]. [cited 2015 april 23]. Available from: http://www.unaids.org/sites/default/files/en/media/unaids/ contentassets/documents/unaidspublication/2012/jc1399_ethical_considerations_en.pdf

8. National Bioethics Advisory Commission (United States of America). Ethical and policy issues in international research: clinical trials in developing countries. 2001. [cited 2015 april 30]. Available from: https://bioethicsarchive.georgetown.edu/nbac/clinical/Vol1.pdf

9. EMA/121340/2011. The European Parliament and of The Council European (Directive 2001/20/EC). [cited 2015 march 29]. Available from: http://ec.europa.eu/health//sites/health/files/files/eudralex/vol-1/dir_2001_20/dir_2001_20_en.pdf

10. UNESCO. Universal Declaration on Bioethics and Human Rights. 2005. [cited 2015 march 29]. Available from: http://portal. unesco.org/en/ev.php-URL_ID=31058\&URL_DO=DO_TOPIC\&URL_SECTION=201.html

11. Schlemper Junior, BR. O placebo e a Declaração de Pachuca: letras mortas? Rev. bioét. (Impr.). 2014; 22 (3): 462-70.

12. Confederación Médica Latinoamericana y del Caribe (CONFEMEL). Declaración de Pachuca sobre la revisión de Helsinki. [Internet]. 16 $6^{\underline{a}}$ Asamblea General Ordinaria; Pachuca, México; 20-23 nov 2013. [acceso 30 marzo 2016]. Disponible en: http://www.confemel. com/test/wp-content/uploads/2015/07/declaracion_helsinki.pdf

13. Gamboa-Bernal GA. La Investigación Biomédica tiene otra versión de la Declaración de Helsinki. Persona y Bioética. 2013;17(2): $145-150$.

14. Kottow M. De Helsinki a Fortaleza: una Declaración desangrada. Rev. bioét. (Impr.). 2014;22(1):28-33.

15. Schlemper Junior BR. Acesso às drogas na pesquisa clínica. Rev Bioética. 2007;15(2): 248-266.

16. Brasil. Agência Nacional de Vigilância Sanitária (ANVISA). RDC No 38/2013. [acesso 15 dez 2016]. Disponível em: http://www. invitare.com.br/pub/RDC_38_de_12_de_agosto_de_2013_b.pdf

17. Brasil. Ministério da Saúde. Conselho Nacional de Saúde. Resoluções - Comissões. Resolução 251/1997 e 466/2012. [acesso 15 dez 2016]. Disponível em: http://conselho.saude.gov.br/web_comissoes/conep/aquivos/resolucoes/resolucoes.htm

18. Conselho Federal de Medicina. Processo-Consulta No 10.090/11. Parecer CFM No 31/2012. [acesso 30 março 2015]. Disponível em: http://www.portalmedico.org.br/pareceres/CFM/2012/31_2012.pdf

19. Supremo Tribunal Federal. Relatório do Ministro Gilmar Mendes. Julgamento em 2009. Processo STA 175 CE. Suspensão de Tutela Antecipada. [acesso 18 fev 2015]. Disponível em: http://www.stf.jus.br/arquivo/cms/noticianoticiastf/anexo/sta175.pdf

20. Conselho Nacional de Justiça. Recomendação No 31/2010. [acesso 18 fev 2015]. Disponível em:

http://www.cnj.jus.br///images/atos_normativos/recomendacao/recomendacao_31_30032010_22102012173049.pdf

21. Advocacia Geral da União. Consultoria-Geral da União. Consultoria Jurídica Junto ao Ministério da Saúde. Parecer No 806/2012 -

AGU/CONJUR-MS/HRP. [acesso 18 fev 2015]. Disponível em: http://www.agu.gov.br/page/download/index/id/23472024

22. Tribunal de Justiça do Rio Grande do Sul. 2ª Vara da Infância e da Juventude. Processo No 1625854. 2009. [acesso 18 fev 2015]. Disponível em: Jornal Jurídico. http://www.jornaljurid.com.br/; http://www.jornaljurid.com.br/noticias/reconhecida-obrigacao-delaboratorios-em-manter-tratamento-apos-termino-de-pesquisa-2009-01-05

23. Ministério Público Federal. Procuradoria Geral da República da $4^{a}$ Região. Parecer 403E/13/MPF/PRR4/HJ (Processo № 5034156-97.2012.404.7100). 2013. [acesso 27 abril 2015]. Disponível em: http://www.prr4.mpf.mp.br/site/index.php?option=com_ content\&view=article\&id=509:mpf-obtem-na-justica-medicamento-para-menor-portador-da-sindrome-de-hunter\&catid=10:noticias\&lte $\operatorname{mid}=58$.

24. CESCR (Comitê Econômico, Social e Cultural). The right to the highest attainable standard of health : 11/08/2000. E/C.12/2000/4. (General Comments). [online]. [cited 2013 april 28] Available from: http://www.unhchr.ch/tbs/doc.nsf/(symbol)/E.C.12.2000.4.En 25. Campos TC. Empresas Transnacionais e Direitos Humanos. Belo Horizonte: Fórum, 2012.

26. Hunt P. The right of everyone to the enjoyment of the highest attainable standard of physical and mental health. [online]. 2006 [cited 2013 April 28]. Available from: http://daccess-dds-y.un.org/doc/UNDOC/GEN/N06/519/97/PDF/N0651997.pdf?OpenElement 27. Grover A. Report of the Special Rapporteur on the right of everyone to the enjoyment of the highest attainable standard of physical and mental health. [online]. 2009 [cited 2013 April 28]. Available from: http://daccess-dds-ny.un.org/doc/UNDOC/GEN/G09/127/11/ PDF/G0912711.pdf?OpenElement

28. Lee JY, Hunt P. Human rights responsabilities of pharmaceutical companies in relation to access to medicines. J Law Med \& Ethics. 2012; 40(2):220-233.

29. Ruggie J. Report of the Special Representative of the Secretary-General on the issue of human rights and transnational corporations 
and other business enterprises 2008. [cited 2015 april 20] Available from: http://www.reports-and-materials.org/sites/default/files/ reports-and-materials/Ruggie-report-7-Apr-2008.pdf.

30. Blackmer J, Haddad H. The Declaration of Helsinki: an update of paragraph 30. Can Med Assoc J. 2005;173(9):1052:1053.

31. Wang DWL, Ferraz OLM. Pharmaceutical Companies vs. The State: Who is responsible for post-trial provisions drugs in Brazil? J Law Med \& Ethics. 2012;40(2):188-196. 